\title{
Uromodulin: old friend with new roles in health and disease
}

\author{
Franca M. Iorember • V. Matti Vehaskari
}

Received: 29 April 2013 /Revised: 16 June 2013 / Accepted: 26 June 2013 / Published online: 24 July 2013

(C) IPNA 2013

\begin{abstract}
The most abundant urinary protein, TammHorsfall protein, later renamed uromodulin, is expressed exclusively by the thick ascending limb cells of the kidney and released into urine from the apical cell membrane. Uromodulin is believed to protect against urinary tract infections and stones, but its other physiologic functions have remained obscure until recently. Renewed interest in uromodulin has been brought about by the identification of uromodulin mutations as causes of a discrete group of diseases that are distinct from nephronophthisis. The three overlapping clinical uromodulin-associated kidney diseases (UAKD) are medullary cystic disease type 2, familial juvenile hyperuricemic nephropathy and glomerulocystic kidney disease. Previously thought of as "adult diseases", it is now recognized that they may also present in childhood and even in infancy. Common characteristics of all three diseases are autosomal dominant inheritance, unremarkable urine sediment and slow progression to end-stage renal disease (ESRD). They are frequently associated with hyperuricemia and gout. These diseases appear to result from failure of the mutant uromodulin to be incorporated into the apical cilium, thereby placing UAKD in the category of "ciliopathies". In addition to causing specific UAKD, certain uromodulin gene polymorphisms have been linked to ESRD in general, suggesting that uromodulin plays a modulatory role in kidney disease progression.
\end{abstract}

Keywords Uromodulin · Tamm-Horsfall protein .

Uromodulin-associated kidney disease .

Medullary cystic kidney disease .

Familial juvenile hyperuricemic nephropathy .

Glomerulocystic disease

F. M. Iorember • V. M. Vehaskari $(\square)$

Division of Pediatric Nephrology, Department of Pediatrics,

Louisiana State University Health Sciences Center, 200 Henry Clay

Avenue, Rm 4241, New Orleans, LA 70118, USA

e-mail: vvehas@1suhsc.edu

\section{Introduction}

Uromodulin, also known as Tamm-Horsfall protein (THP), was first described by Tamm and Horsfall in 1950 as a urinary mucoprotein that is able to inhibit viral agglutination [1]. In 1985, Muchmore and Decker isolated an $85-\mathrm{kDa}$ glycoprotein with potent immunosuppressive properties from the urine of pregnant women and named it "uromodulin" to reflect its origin in the urine and its ability to inhibit antigen-induced T-cell proliferation and monocyte cytotoxicity in vitro [2]. This glycoprotein was subsequently confirmed to be THP by Pennica et al. [3].

Despite being expressed only in the kidney and being the most abundant protein in human urine, the physiologic role of uromodulin has long remained poorly defined. The recognition of diseases caused by uromodulin gene (UMOD) mutations, termed uromodulin-associated kidney diseases (UAKD), has brought renewed interest in uromodulin. Although these diseases were previously thought of as "adult kidney diseases", it has become clear that they may be present early in life, even in infants, and pediatric nephrologists should therefore be familiar with this group of disorders. Of even greater potential importance is the emerging epidemiologic evidence that uromodulin polymorphism may modulate kidney disease and the development of end-stage renal disease (ESRD) regardless of the specific diagnosis. Recent experimental and human research offers new insights into the physiology and pathophysiology of uromodulin, holding promise for the development of improved treatments.

\section{Molecular biology of uromodulin}

The UMOD gene is located at chromosome 16p12.316 p13.11 and is shown to comprise 11-12 exons [4-6]. Uromodulin is produced exclusively by the epithelial cells of the thick ascending limb (TAL) of the loop of Henle. It is a glycosylphosphatidylinositol (GPI)-anchored apical membrane protein, released into the tubular lumen through proteolytic cleavage at a rate of about $50 \mathrm{mg} /$ day [7-9]. Urine uromodulin consists of 640 amino acids, 48 of which are cysteine residues. 
The cysteine residues are involved in 24 disulfide bridges, which is important for the conformation of the protein $[7,8$, 10]. The protein sequence (Fig. 1) contains an N-terminal signal peptide of 24 amino acids, followed by three epidermal growth factor-like domains, a zona pellucida (ZP) domain and a GPI anchor attachment site. The original intracellular Cterminal peptide consists of hydrophobic amino acids, which act as a signal for endoplasmic reticulum (ER)-transpeptidase. After cleavage of the hydrophobic peptide by this enzyme, a preformed GPI anchor is added to the "new" C-terminus [7, 8, 10, 11]. After further maturation in the Golgi apparatus, uromodulin is transported to the apical plasma membrane in a polymerization-incompetent conformation and released into the tubular lumen following proteolytic cleavage by a yet to be identified protease. Cleavage is necessary for polymerization of uromodulin monomers in the tubular lumen, a process likely facilitated by the ZP domain [10,11].

\section{Functions of uromodulin}

The physiologic functions of uromodulin are yet to be fully elucidated, but they are likely to be related to its exclusive location in the TAL and to its connection with the apical cilium. Other functions may be related to the large quantities excreted in urine and its immunomodulatory properties. To maintain the efficiency of the countercurrent concentrating mechanism, the electrolyte-transporting TAL has to be impermeable to water. There is evidence that uromodulin in the polymerized form contributes to the water impermeability of TAL [5]. In addition, uromodulin increases membrane expression of the renal outer medullary potassium channel (ROMK2) and activates the TAL
$\mathrm{N}-\mathrm{K}-2 \mathrm{Cl}$ co-transporter in vitro $[12,13]$. Disruption of these pathways may contribute to the mild salt and water wasting seen in $U M O D$ mutations, but this remains to be studied.

Urine uromodulin may play an important role in bladder mucosal defense against infections [14]. Recurrent urinary tract infections (UTIs) in children with $U M O D$ mutations have been reported [15], and $U M O D$ knock-out mice have increased susceptibility to UTIs [16]. Several findings suggest that uromodulin may act as a defense against stone formation. Uromodulin deficiency in humans may be a risk factor for nephrolithiasis. UMOD knock-out mice models have shown a propensity for increased calcium crystal formation in the urinary tract and a reduced ability to inhibit the adhesion of calcium oxalate monohydrate crystals to renal epithelial cells $[17,18]$.

Finally, recent experimental data suggest that uromodulin may play a protective role in acute kidney injury by decreasing inflammation and enhancing recovery. Uromodulin knock-out mice were shown to develop more functional and histologic renal damage and had delayed recovery after ischemia-reperfusion injury compared to wild-type mice [19]. Another study by the same group showed that uromodulin expression is down-regulated at the peak of acute kidney injury and up-regulated $48 \mathrm{~h}$ after ischemia-reperfusion injury [20]. These findings are yet to be confirmed in humans.

\section{Uromodulin-associated kidney diseases}

\section{Pathophysiology}

The existence of renal disease caused by $U M O D$ mutations has been known for some time, but the phenotypic and genotypic
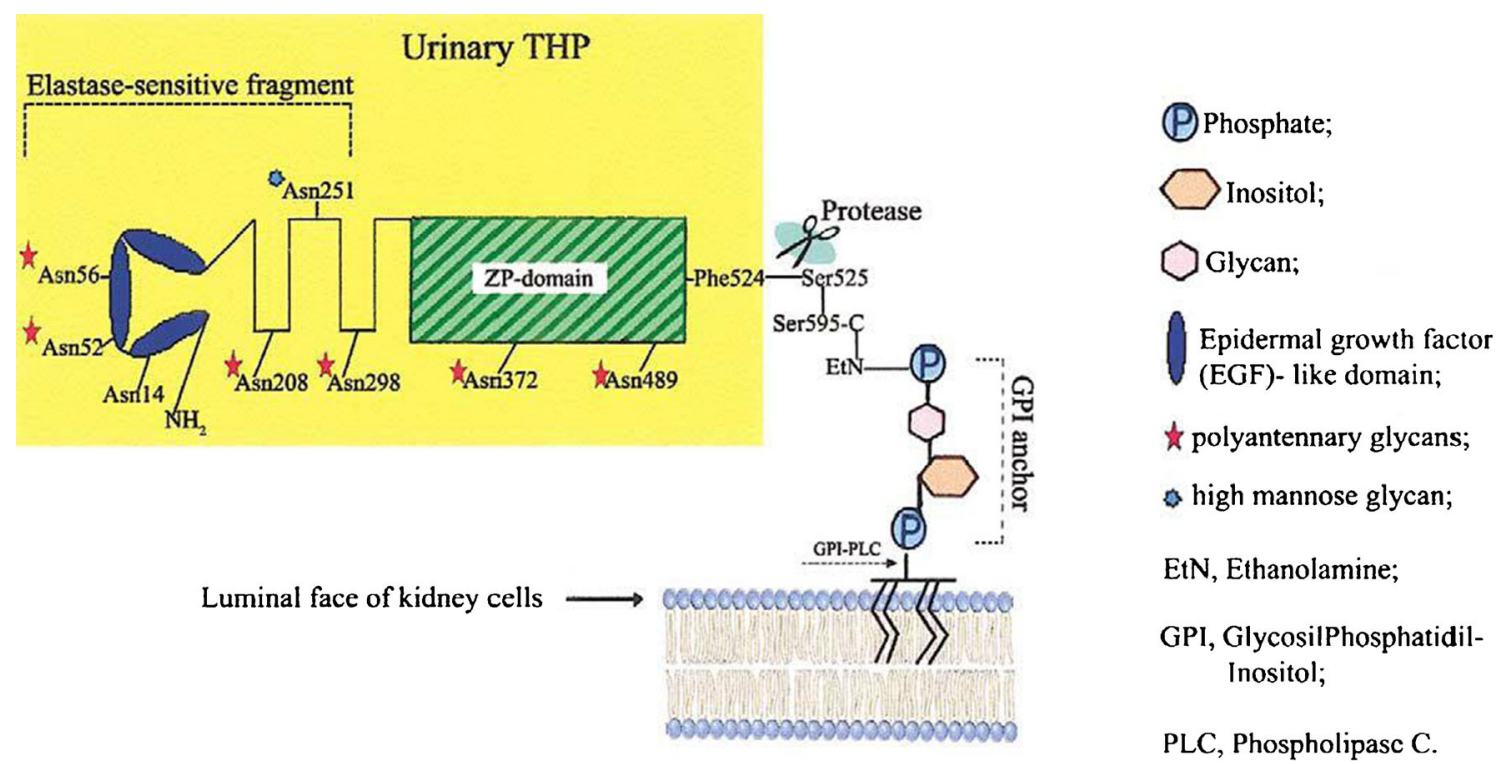

Fig. 1 Structural model of urinary uromodulin [Tamm-Horsfall protein $(T H P)$, yellow area] and its renal glycosylphosphatidylinositol $(G P I)-$ anchored counterpart. ZP Zona pellucida. Reproduced with permission from Vyletal et al. [5] 
features have only recently been characterized in detail. Collectively termed UAKD, they were initially lumped into the "nephronophthisis-medullary cystic disease complex," but are now recognized as a distinctly separate group of diseases. UAKD are inherited in autosomal dominant fashion. Incomplete penetrance and de novo mutations may explain the absence of a family history in some patients [21]. To date, over 50 UMOD mutations have been described, of which $>90 \%$ are missense mutations and $>60 \%$ affect the cysteine residues. The majority of these mutations are clustered in exons 4 and 5 and located in the N-terminal half of the protein [21-25]. The mutations cause significantly delayed maturation and trafficking of the mutant uromodulin, which in turn results in its retention in the ER, reduced expression at the plasma membrane, and decreased secretion into the tubular lumen [24, 26-28].

The mechanism of the progressive tubulointerstitial injury in UAKD is not clear. It has been shown that the mutant uromodulin cannot exit the ER of TAL cells, resulting in intracellular accumulation of the mutant protein and consequent cell damage $[24,26,27]$. This may incite an immune response with infiltration of immune cells and pro-fibrinogenic lymphokine production in the tubulointerstitium [29].

Increased plasma uric acid level and decreased fractional excretion of uric acid are frequently present in UAKD. Hyperuricemia is speculated to result from increased proximal tubular water and solute (including uric acid) reabsorption secondary to mild volume depletion caused by impaired distal tubule salt and water reabsorption [21]. The potential role of renal uric acid accumulation in the pathogenesis of UAKD is unknown. Uric acid crystals are not typically seen in tissue specimens [30]. A recent hypothesis linking uric acid to renal vascular damage and the development of chronic kidney disease (CKD) may provide a partial explanation [31].

New insight into the pathophysiology of UAKD has been provided by recent reports linking uromodulin to the central apical cilium of TAL cells and demonstrating decreased ciliary uromodulin expression in biopsy tissue from UAKD patients [32], suggesting that UAKD belongs to the group of diseases termed "ciliopathies." This group includes polycystic kidney diseases (PKD) and nephronophthisis. The kidney injury and cyst formation in ciliopathies, presumably including UAKD, are believed to result from dysfunctional cilium, although the exact mechanisms remain to be worked out. The cilium is in a position to use extracellular signals such as luminal flow to trigger intracellular signaling that may be vital for cell integrity [33].

\section{Clinical features}

Three chronic tubulointerstitial diseases have been associated with $U M O D$ mutations [25, 34]: familial juvenile hyperuricemic nephropathy (FJHN), medullary cystic kidney disease type 2 (MCKD 2), and glomerulocystic kidney disease (GCKD).
Mutations in separate domains of the $U M O D$ gene may result in similar clinical phenotypes and, conversely, seemingly identical mutations may lead to any of the three phenotypes [15, 35], suggesting that other modifying genetic or environmental factors play a role. This notion is supported by the demonstration of wide intrafamilial variation in the severity of UAKD [21]. Some authors consider all three disorders part of the same disease spectrum $[15,21,36]$.

The three UAKD share many clinical features. There is typically a long asymptomatic period during which only high index of suspicion, for instance prompted by family history, may lead to diagnosis. More commonly, laboratory or clinical signs of decreased kidney function trigger evaluation at a later age. It is suspected that many young adults developing "ESRD of unknown etiology" do, in fact, have inherited tubulointerstitial disease. Blood pressure is usually normal or borderline low due to salt wasting. Urine sediment is bland except in advanced diseases when proteinuria may appear, but a mild concentrating defect is usually demonstrable. Elevated plasma uric acid level and decreased fractional excretion of uric acid are more specific to UAKD, but considerable overlap with normal values exists, especially in females [34]. With declining glomerular filtration rate (GFR) the hyperuricemia tends to be disproportionate to the level of renal impairment. For example, a study of young adults with mild to severe CKD showed that across all GFR levels approximately $50 \%$ of UAKD patients had plasma uric acid levels above the 90th percentile of the other CKD patients; low fractional excretion of uric acid was below the 10th percentile in $48 \%$ of the UAKD patients [21]. Hyperuricemia may be present in family members without overt renal disease. Gout is common in family members but less frequently seen in pediatric patients.

Urinary tract imaging is usually normal in early stages, but hypoplastic kidneys and vesicoureteral reflux have been reported in some series [15]. Histology is non-specific with chronic tubulointerstitial nephritis, thickening of tubular basement membrane, and possibly small cysts. Glomeruli are spared until late in the disease, except in GCKD. A potential future diagnostic tool is immunohistochemical staining for uromodulin which would be expected to demonstrate decreased apical and increased intracellular staining in TAL cells.

Familial juvenile hyperuricemic nephropathy

The typical age of onset of FJHN is between 3 and 17 years but it may be younger [37, 38]. Hyperuricemia and gout are more common in FJHN than in the other UAKD. In those who present with renal failure, hyperuricemia is invariably present [37-39]. Mild concentrating defect is present early and may be associated with enuresis but mostly goes unnoticed. ESRD typically ensues in young adulthood. Renal biopsy findings are nonspecific. As a rule, cysts are not present, but microscopic corticomedullary cysts are occasionally seen. 
Medullary cystic kidney disease type 2

The phenotypic features of MCKD2 overlap those of FJHN and are characterized by hyperuricemia, precocious gout, and progressive tubulointerstitial nephropathy. ESRD typically is not reached until mid- to late adulthood. Although MCKD 2 was previously described to have an age of onset between 20 and 30 years, recent studies have shown disease presentation in children as young as 7 years [40]. Children are often asymptomatic but may present with renal insufficiency. Gout may develop after adolescence. Renal imaging may show the presence of cysts. Histology is similar to FJHN except for the more frequent presence of corticomedullary cysts $[15,34]$. (Note that MCKD 1 is not caused by a UMOD mutation and will be discussed below under Diagnosis).

Glomerulocystic kidney disease

Glomerulocystic kidney disease is not a single entity but can be associated with several hereditary disorders, including autosomal dominant $U M O D$ mutation and autosomal dominant polycystic kidney disease (ADPKD). Renal cysts and diabetes (RCAD), caused by a mutation in the hepatocyte nuclear factor $1-\beta$, a transcription factor which modulates the expression of uromodulin [41], is also associated with GCKD. Sporadic forms of GCKD have been described and may represent new mutations of the same diseases. Lack of wide-spread genetic testing has so far prevented accurate determination of the percentage of cases that are caused by UMOD mutations. Early-onset GCKD may be diagnosed in newborns and young children; late-onset GCKD commonly does not present until adulthood. Children may be discovered to have renal insufficiency on routine laboratory tests. Hyperuricemia may be present. Kidneys in affected infants and children may be hypoplastic or normal size on a renal ultrasound scan. Histology is similar to other UAKD except for the presence of cystic dilatation of the Bowman's space and the initial proximal convoluted tubule as well as collapse of the glomerular tuft (Fig. 2) [42]. GDKD in most cases progresses to ESRD, but the rate of progression is highly variable.
Treatment

In patients with FJHN, early treatment with allopurinol (while renal function is still normal or only mildly reduced) has been shown to lower serum uric acid levels, stabilize renal function and delay the progression of renal failure. The treatment is empirical; allopurinol does not have an effect on the fractional excretion of uric acid [43]. Benzbromarone is an agent known to increase the fractional excretion of uric acid and has been reported to also stabilize renal function in some patients with FJHN [44]. In contrast to FJHN, no specific therapy has been described in the other UAKD, but one might expect similar strategies to be effective in slowing the progression of the disease. Because the defect is in intracellular trafficking of the mutant protein, treatment with an appropriate "chaperone" to allow its insertion into the apical membrane offers hope for the future [45].

\section{Uromodulin and CKD}

Apart from the rare autosomal dominant diseases caused by $U M O D$ mutations, emerging epidemiologic evidence suggests that uromodulin may play a much more widespread role in the development and progression of CKD in general. Genome-wide association studies have identified $U M O D$-associated single nucleotide polymorphisms (SNPs) that may either predispose an individual to CKD or accelerate the progression of CKD [46]. Conversely, some SNPs have been reported to be protective against CKD [47]. Although further independent confirmation is necessary, these findings suggest a non-specific effect of uromodulin polymorphism on renal function irrespective of underlying primary renal disease.

Another possible role of uromodulin in CKD involves secondary tissue injury. A primary renal disease may lead to interstitial uromodulin accumulation due to the release of uromodulin from diseased TAL cells or to backleak from the tubular lumen. In either case, the hypothesis is that uromodulin stimulates a local immune response which in turn accelerates
Fig. 2 Glomerulocystic kidney disease. Glomerular cysts are characterized by enlarged Bowman's space and shrunken glomerular tufts. Original magnification: a 100, b $400 \times$ (Courtesy of Dr. Randall Craver)

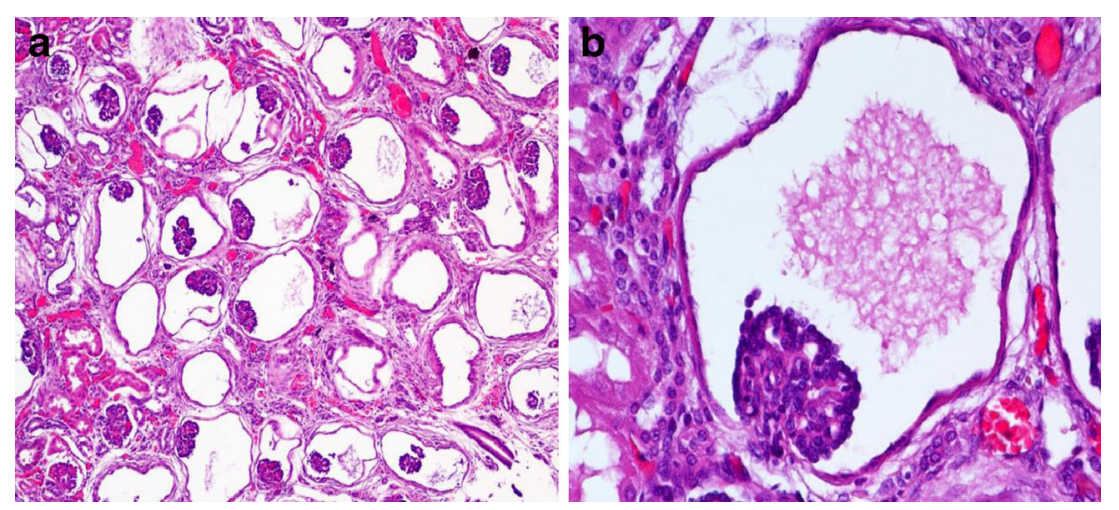


the tubulointerstitial damage [48]. This concept is supported by animal studies showing that the presence of uromodulin in the blood causes a predominantly cellular immune response directed at uromodulin that results in tubulointerstitial nephritis [49].

\section{Diagnosis of UAKD}

As discussed above, making the diagnosis of UAKD requires a high index of suspicion and is supported by a positive family history of CKD or gout. The only specific laboratory test is plasma uric acid; elevated or a high-normal level should prompt the measurement of fractional excretion of uric acid (normal range 6-20\%). Urine sediment, at least in the early stages, is benign and renal ultrasound nondiagnostic. Renal biopsy is not routinely indicated but may be performed to rule out other diseases. Genetic testing for known $U M O D$ mutations confirms the diagnosis if positive but may not be definitive in the case of new mutations. Resources for genetic testing can be found at http://www. ncbi.nlm.nih.gov/projects/GeneTests/static/whatsnew/notice. shtml. The diagnostic utility of urine uromodulin excretion remains to be established.

A differential diagnostic list is presented in Table 1. It may be impossible to distinguish between the three UAKD because of the overlapping clinical and laboratory features. MCKD type 1 is clinically identical to MCKD2 except for less common presence of hyperuricemia in early disease. A recent report suggests that it may be caused by a mutation in the Mucin 1 gene on chromosome 1 [50]. Some types of nephronophthisis may resemble UAKD, but the inheritance is autosomal recessive and renal ultrasound may show cysts or other abnormalities; various extrarenal manifestations are present in some types of nephronophthisis. RCAD is usually associated with macroscopic renal cysts; diabetes and hyperuricemia are not always present [51]. ADPKD and autosomal recessive PKD are usually easily ruled out by renal ultrasound. The clinical phenotype of rare renin (REN) gene mutations is indistinguishable from UMOD mutations except for the presence of severe anemia and lower blood pressures [52]. Note that the genetic defect is still unknown in a number of individuals whose clinical picture resembles that of UAKD.

\section{Summary points}

- Uromodulin, present in TAL apical membrane, is important for TAL integrity and transport characteristics.

- Uromodulin is secreted in large quantities in urine and may protect against stones and urinary tract infections.

- $U M O D$ mutations cause UAKD, autosomal dominant tubulointerstitial nephritides that belong to the ciliopathy group of hereditary kidney diseases.

- UAKD patients are frequently asymptomatic and lack diagnostic laboratory, imaging, and histologic features.

Table 1 Differential diagnosis of uromodulin-associated kidney diseases

\begin{tabular}{|c|c|c|c|c|c|c|}
\hline Parameters & $\begin{array}{l}\text { Familial juvenile } \\
\text { hyperuricemic } \\
\text { nephropathy }\end{array}$ & $\begin{array}{l}\text { Medullary cystic } \\
\text { kidney disease } \\
\text { type } 2\end{array}$ & $\begin{array}{l}\text { Medullary cystic } \\
\text { kidney disease } \\
\text { type } 1\end{array}$ & $\begin{array}{l}\text { Glomerulocystic } \\
\text { kidney disease }\end{array}$ & Renal cysts and diabetes & Nephronophthisis \\
\hline Inheritance & $\mathrm{AD}$ & $\mathrm{AD}$ & $\mathrm{AD}$ & $\mathrm{AD}$ & $\mathrm{AD}$ & $\mathrm{AR}$ \\
\hline Gene & $U M O D$ & $U M O D$ & Mucin $1 ?$ & $U M O D$ & $H N F 1 \beta$ & $\begin{array}{l}\text { Several, many } \\
\text { unknown }\end{array}$ \\
\hline $\begin{array}{l}\text { Typical age at } \\
\text { presentation }\end{array}$ & $\begin{array}{l}\text { Infancy to } \\
\text { adulthood }\end{array}$ & $\begin{array}{l}\text { Adolescence to } \\
\text { adulthood }\end{array}$ & Adulthood & $\begin{array}{l}\text { Infancy to } \\
\text { adolescence }\end{array}$ & Infancy, childhood & $\begin{array}{l}\text { Infancy to } \\
\text { adolescence }\end{array}$ \\
\hline $\begin{array}{l}\text { Typical age at } \\
\text { ESRD }\end{array}$ & $\begin{array}{l}\text { 2nd through 4th } \\
\text { decade }\end{array}$ & After 4th decade & Adulthood & Any age & Childhood to adulthood & $\begin{array}{l}\text { Childhood, } \\
\text { adolescence }\end{array}$ \\
\hline Hyperuricemia & Most patients & Common & $\begin{array}{l}\text { Minority of } \\
\text { patients }\end{array}$ & $\begin{array}{l}\text { Minority of } \\
\text { patients }\end{array}$ & Minority of patients & No \\
\hline Gout & $\begin{array}{l}\text { Common, less } \\
\text { frequent in } \\
\text { females }\end{array}$ & $\begin{array}{l}\text { Uncommon } \\
\text { before } \\
\text { adulthood }\end{array}$ & Uncommon & Uncommon & Uncommon & No \\
\hline Other features & & & & $\begin{array}{l}\text { Severe urine } \\
\text { concentrating } \\
\text { defect }\end{array}$ & $\begin{array}{l}\text { Diabetes, abnormal liver } \\
\text { function, genitourinary } \\
\text { malformations }\end{array}$ & $\begin{array}{l}\text { Anemia, growth } \\
\text { failure, extrarenal } \\
\text { manifestations }\end{array}$ \\
\hline $\begin{array}{l}\text { Renal } \\
\text { morphology }\end{array}$ & $\begin{array}{l}\text { NTIN, cysts } \\
\text { uncommon }\end{array}$ & $\begin{array}{l}\text { NTIN, } \\
\text { microscopic or } \\
\text { macroscopic } \\
\text { cysts }\end{array}$ & $\begin{array}{l}\text { NTIN, no or only } \\
\text { microscoipc } \\
\text { cysts }\end{array}$ & $\begin{array}{l}\text { NTIN, } \\
\text { glomerular } \\
\text { cysts }\end{array}$ & $\begin{array}{l}\text { NTIN, macroscopic cysts } \\
\text { common, renal } \\
\text { malformations }\end{array}$ & $\begin{array}{l}\text { NTIN, microscopic } \\
\text { cysts }\end{array}$ \\
\hline
\end{tabular}

ESRD, End-stage renal disease; AD, autosomal dominant; NTIN, nonspecific tubulointerstitial nephropathy; AR autosomal recessive 
Progression to ESRD is the rule, but the rate of progression is highly variable.

- UAKD are frequently associated with hyperuricemia and gout in patients or family members.

\section{Future considerations}

Although significant advances have been made in understanding the functions of uromodulin, further research is needed to more clearly define its role in human physiology. $U M O D$ mutations cause misfolding of uromodulin leading to its retention in the ER. Chemical chaperones have been demonstrated to significantly alter mutant uromodulin retention in the ER and its translocation to the plasma membrane. Such an intervention holds great promise as a treatment strategy that can alter disease progression in patients with UAKD.

\section{Multiple choice questions (answers are provided following the reference list)}

1. A 15-year-old girl is evaluated for mild abdominal pain and is found to have a serum creatinine level of $1.5 \mathrm{mg} / \mathrm{dL}$. Urinalysis shows the following: urine specific gravity, 1.010; $\mathrm{pH} 7.0$; protein, negative; blood, negative; no cells. Renal ultrasound is normal except for slightly increased echogenicity.

Which of the following would be the most appropriate next diagnostic test?
A. Renal biopsy
B. Genetic testing
C. Computed tomography (CT) scan of kidneys
D. Plasma uric acid level
E. Urine uromodulin excretion

2. Which of the following is true regarding uromodulinassociated kidney diseases?
A. Genetic analysis will differentiate between the dif- ferent types
B. Mutations usually occur in the C-terminal half of the protein
C. Most mutations are large deletions
D. The mutant protein is degraded in lysosomes
E. The mutant protein is trapped in the endoplasmic reticulum

3. Which of the following is true regarding uromodulinassociated kidney diseases?
A. Family history will predict the rate of progression
B. Identical mutation may cause any of the disorders
C. Family history correlates with age of presentation
D. Family history always includes gout

E. Some pedigrees show autosomal recessive inheritance

4. Features of uromodulin-associated kidney disease include which of the following?
A. Increased intracellular expression of uromodulin
B. Increased apical membrane expression of uromodulin
C. Increased urinary excretion of uromodulin
D. Decreased intracellular expression of uromodulin
E. Increased fractional excretion of uric acid

5. Which of the following is associated with uromodulin mutations in pediatric patients?
A. Short stature
B. Anemia
C. Proteinuria
D. Liver dysfunction
E. Enuresis

\section{References}

1. Tamm I, Horsfall FL (1950) Characterization and separation of an inhibitor of viral hemagglutination present in urine. Proc Soc Exp Biol Med 74:108-114

2. Muchmore AV, Decker JM (1985) Uromodulin: a unique 85kiloDalton immunosuppressive glycoprotein isolated from urine of pregnant women. Science 229:479-481

3. Pennica D, Kohr WJ, Kuang WJ, Glaister D, Aggarwal BB, Chen EY, Goeddel DV (1987) Identification of human uromodulin as the Tamm-Horsfall urinary glycoprotein. Science 236:83-88

4. Pook MA, Jeremiah S, Scheinman SJ, Povey S, Thakker RV (1993) Localization of the Tamm-Horsfall glycoprotein (uromodulin) gene to chromosome 16p12.3-16p13.11. Ann Hum Genet 57:285290

5. Vyletal P, Bleyer AJ, Kmoch S (2010) Uromodulin biology and pathophysiology-an update. Kidney Blood Press Res 33:456-475

6. Wei X, Xu R, Yang Z, Li Z, Liao Y, Johnson R, Yu X, Chen W (2012) Novel uromodulin mutation in Familial Juvenile hyperuricemic nephropathy. Am J Nephrol 36:114-120

7. Santambrogio S, Cattaneo A, Bernascone I, Schwend T, Jovine L, Bachi A, Rampoldi L (2008) Urinary uromodulin carries an intact ZP domain generated by a conserved C-terminal proteolytic cleavage. Biochem Biophys Res Commun 370:410-413

8. Serafini-Cessi F, Malagolini N, Cavallone D (2003) TammHorsfall glycoprotein: biology and clinical relevance. Am J Kidney Dis 42:658-676

9. Devuyst O, Dahan K, Pirson Y (2004) Tamm-Horsfall protein or uromodulin: new ideas about an old molecule. Nephrol Dial Transplant 20:1290-1294

10. Rampoldi L, Scolari F, Amoroso A, Ghiggeri G, Devuyst O (2011) The rediscovery of uromodulin (Tamm-Horsfall protein): from tubulointerstitial nephropathy to chronic kidney disease. Kidney Int 80:338-347

11. Schaeffer C, Santambrogio S, Perucca S, Casari G, Rampoldi L (2009) Analysis of uromodulin polymerization provides New insights into the mechanisms regulating ZP domain-mediated protein assembly. Mol Biol Cell 20:589-599

12. Renigunta A, Renigunta V, Saritas T, Decher N, Mutig K, Waldegger S (2011) Tamm-Horsfall glycoprotein interacts with 
renal outer medullary potassium channel ROMK2 and regulates its function. J Biol Chem 286:2224-2235

13. Mutig K, Kahl T, Saritas T, Godes M, Persson P, Bates J, Raffi H, Rampoldi L, Uchida S, Hille C, Dosche C, Kumar S, CastanedaBueno M, Gamba G, Bachmann S (2011) Activation of the bumetanide-sensitive $\mathrm{Na}+, \mathrm{K}+, 2 \mathrm{Cl}$ - cotransporter ( $\mathrm{NKCC} 2$ ) is facilitated by Tamm-Horsfall protein in a chloride-sensitive manner. J Biol Chem 286:30200-30210

14. Akiyama A, Stein PC, Houshiar A, Parsons CL (2000) Urothelial cytoprotective activity of Tamm-Horsfall protein isolated from the urine of healthy subjects and patients with interstitial cystitis. Int J Urol 7:176-183

15. Wolf MTF, Beck BB, Zaucke F, Kunze A, Misselwitz J, Ruley J, Ronda T, Fischer A, Eifinger F, Licht C, Otto E, Hoppe B, Hildebrandt F (2006) The uromodulin C744G mutation causes MCKD2 and FJHN in children and adults and may be due to a possible founder effect. Kidney Int 71:574-581

16. Mo L, Zhu X, Huang H, Shapiro E, Hasty D, Wu X (2004) Ablation of the Tamm-Horsfall protein gene increases susceptibility of mice to bladder colonization by type 1-fimbriated Escherichia coli. Am J Physiol Ren Physiol 286:F95-F802

17. Mo L, Liaw L, Evan AP, Sommer AJ, Lieske JC, Wu X (2007) Renal calcinosis and stone formation in the mice lacking osteopontin, Tamm-Horsfall protein or both. Am J Physiol Ren Physiol 293: F1935-F1943

18. Mo L, Huang H, Zhu X, Shapiro E, Hasty D, Wu X (2004) TammHorsfall protein is a critical renal defense factor protecting against calcium oxalate crystal formation. Kidney Int 66:1159-1166

19. El-Achkar TM, Wu X, Rauchman M, McCracken R, Keifer S, Dagher PC (2008) Tamm-Horsfall protein protects the kidney from ischemic injury by decreasing inflammation and altering TLR4 expression. Am J Physiol Ren Physiol 295:F534-F544

20. El-Achkar TM, McCracken R, Liu Y, Heitmeier MR, Bourgeois S, Ryerse J, Wu X (2013) Tamm-Horsfall protein translocates to the basolateral domain of thick ascending limbs, interstitium and circulation during recovery from acute kidney injury. Am J Physiol Ren Physiol 304:F1066-F1075

21. Bollee G, Dahan K, Flamant M, Moriniere V, Pawtowski A, Heidet L, Lacombe D, Devuyst O, Pirson Y, Antignac C, Knebelmann B (2011) Phenotype and outcome in hereditary tubulointerstitial nephritis secondary to $U M O D$ mutations. Clin J Am Soc Nephrol 6:2429-2438

22. Dahan K, Devuyst O, Smaers M, Vertommen D, Loute G, Poux J, Viron B, Jacquot C, Gagnadoux M, Chauveau D, Buchler M, Cochat P, Cosyns J, Mougenot B, Rider M, Antignac C, Verellen-dumoulin C, Pirson Y (2003) A cluster of mutations in the UMOD gene causes familial juvenile hyperuricemic nephropathy with abnormal expression of uromodulin. J Am Soc Nephrol 14:2883-2893

23. Schaeffer C, Cattaneo A, Trudu M, Santambrogio S, Bernascone I, Giachino D, Caridi G, Campo A, Murtas C, Benoni S, Izzi C, Marchi M, Amoroso A, Ghiggeri GM, Scolari F, Bachi A, Rampoldi L (2012) Urinary secretion and extracellular aggregation of mutant uromodulin isoforms. Kidney Int 81:769-778

24. Wolf MTF, Mucha BE, Attanasio M, Zalewski I, Karle SM, Neumann HPH, Rahman N, Bader B, Baldamus CA, Otto E, Witzgall R, Fuchshuber A, Hilderbrandt F (2003) Mutations of the Uromodulin gene in MCKD type 2 patients cluster in exon 4, which encodes three EGF-like domains. Kidney Int 64:1580-1587

25. Lens XM, Banet JF, Outeda P, Barrio-Lucia V (2005) A novel pattern of mutation in uromodulin disorders: autosomal dominant medullary cystic kidney disease type 2, Familial Juvenile hyperuricemic nephropathy, and autosomal dominant glomerulocystic kidney disease. Am J Kidney Dis 46:52-57

26. Williams SE, Reed AAC, Galvanovskis J, Antignac C, Goodship T, Karet FE, Kotanko P, Lhotta K, Moriniere V, Williams P, Wong W, Rorsman P, Thakker RV (2009) Uromodulin mutations causing familial juvenile hyperuricaemic nephropathy lead to protein maturation defects and retention in the endoplasmic reticulum. Hum Mol Genet 18:2963-2974

27. Bernascone I, Vavassori S, Pentima AD, Santambrogio S, Lamorte G, Amoroso A, Scolari F, Ghiggeri GM, Casari G, Polishchuk R, Rampoldi L (2006) Defective intracellular trafficking of uromodulin mutant isoforms. Traffic 7:1567-1579

28. Jennings P, Aydin S, Kotanko P, Lechner J, Lhotta K, Williams S, Thakker RV, Pfaller W (2007) Membrane targeting and secretion of mutant uromodulin in familial juvenile hyperuricemic nephropathy. J Am Soc Nephrol 18:264-273

29. Liu Y, El-Achkar T, Wu X (2012) Tamm-Horsfall protein regulates circulating and renal cytokines by affecting glomerular filtration rate and acting as a urinary cytokine trap. J Biol Chem 287:16365-16378

30. Kang DH, Nakagawa T, Feng L, Watanabe S, Han L, Mazzali M, Truong L, Harris R, Johnson RJ (2002) A role for uric acid in the progression of renal disease. J Am Soc Nephrol 13:2888-2897

31. Johnson RJ, Nakagawa T, Jalal D, Sanchez-Lozada LG, Kang D, Ritz E (2013) Uric acid and chronic kidney disease: which is chasing which? Nephrol Dial Transplant. doi:10.1093/ndt/gft029

32. Zaucke F, Boehnlein JM, Steffens S, Polishchuk RS, Rampoldi L, Fischer A, Pasch A, Boehm CWA, Baasner A, Attanasio M, Hoppe B, Hopfer H, Beck BB, Sayer JA, Hildebrandt F, Wolf MTF (2010) Uromodulin is expressed in renal primary cilia and UMOD mutations result in decreased ciliary uromodulin expression. Hum Mol Genet 9:1985-1997

33. Deltas C, Papagregorio G (2010) Cystic diseases of the kidney. Arch Pathol Lab Med 134:569-582

34. Hart TC, Gorry MC, Hart PS, Woodard AS, Shihabi Z, Sandhu J, Shirts B, Xu L, Zhu H, Barmada MM, Bleyer AJ (2002) Mutations of the UMOD gene are responsible for medullary cystic kidney disease 2 and familial juvenile hyperuricaemic nephropathy. J Med Genet 39:882-892

35. Rampoldi L, Caridi G, Santon D, Boaretto F, Bernascone I, Lamorte G, Tardanico R, Dagnino M, Colussi G, Scolari F, Ghiggeri GM, Amoroso A, Casari G (2003) Allelism of MCKD, FJHN and GCKD caused by impairment of uromodulin export dynamics. Hum Mol Genet 12:3369-3384

36. Dahan K, Fuchshuber A, Adamis S, Smears M, Kroiss S, Loute G, Cosyns J, Hildebrandt F, Verellen-dumoulin C, Pirson Y (2001) Familial juvenile hyperuricemic nephropathy and autosomal dominant medullary cystic kidney disease type 2: Two facets of the same disease? J Am Soc Nephrol 12:2348-2357

37. McBride MB, Rigden S, Haycock GB, Dalton N, Hoff WV, Rees L, Raman GV, Moro F, Ogg CS, Cameron JS, Simmonds HA (1997) Presymptomatic detection of familial juvenile hyperuricaemic nephropathy in children. Pediatr Nephrol 12:357-364

38. Schäffer P, Gombos E, Meichelbeck K, Kiss A, Hart PS, Bleyer AJ (2010) Childhood course of renal insufficiency in a family with a uromodulin gene mutation. Pediatr Nephrol 25:1355-1360

39. Lee DH, Kim JK, Oh SE, Noh JW, Lee Y (2010) A case of Familial Juvenile hyperuricemic nephropathy with novel uromodulin gene mutation, a novel heterozygous missense mutation in Korea. J Korean Med Sci 25:1680-1682

40. Bleyer AJ, Hart TC, Willingham MC, Iskandar SS, Gorry MC, Trachtman H (2005) Clinico-pathologic findings in medullary cystic kidney disease type 2. Pediatr Nephrol 20:824-827

41. Gresh L, Fischer E, Reimann A, Tanguy M, Garbay S, Shao X, Hiesberger T, Fiette L, Igarashi P, Yaniv M, Pontoglio M (2004) A transcriptional network in polycystic kidney disease. EMBO J 23:1657-1668

42. Sharp CK, Bergman SM, Stockwin JM, Robbin ML, Galliani C, Guay-Woodford LM (1997) Dominantly transmitted glomerulocystic kidney disease: a distinct genetic entity. J Am Soc Nephrol 8:77-84

43. Fairbanks LD, Cameron JS, Venkat-Raman G, Rigden SPA, Rees L, Hoff WV, Mansell M, Pattison J, Goldsmith DJA, Simmonds 
HA (2002) Early treatment with allopurinol in familial juvenile hyperuricaemic nephropathy (FJHN) ameliorates the long-term progression of renal disease. Q J Med 95:597-607

44. Lhotta K, Gruber J, Sgonc R, Fend F, Konig P (1998) Apoptosis of tubular epithelial cells in familial juvenile gouty nephropathy. Nephron 79:340-344

45. Ma L, Liu Y, El-Achkar TM, Wu X (2012) Molecular and cellular effects of tamm-horsfall protein mutations and their rescue by chemical chaperones. J Biol Chem 287:1290-1305

46. Lhotta K (2010) Uromodulin and chronic kidney disease. Kidney Blood Press Res 33:393-398

47. Reznichenko A, Boger CA, Sneider H, van den Born J, de Borst MH, Damman J, van Dijk M, van Goor H, Hepkema BG, Hillebrands J, Leuvenink HGD, Niesing J, Bakker SJL, Seelen M, Navis G (2012) $\mathrm{UMOD}$ as a susceptibility gene for end-stage renal disease. BMC Med Genet 13:78

48. Prajczer S, Heidenreich U, Pfaller W, Kotanko P, Lhotta K, Jennings $P$ (2010) Evidence for a role of uromodulin in chronic kidney disease progression. Nephrol Dial Transplant 25:1896-1903

49. Mayrer A, Kashgarian M, Ruddle NH, Marier R, Hodson CJ, Richards FF, Andriole VT (1982) Tubulointerstitial nephritis and immunologi responses to tamm-horsfall protein in rabbits challenged with homologous urine or tamm-horsfall protein. J Immunol 128:2634-2642

50. Kirby A, Gnirke A, Jaffe DB, Barešová V, Pochet N, Blumenstiel B, Ye C, Aird D, Stevens C, Robinson JT, Cabili MN, Gat-Viks I, Kelliher E, Daza R, DeFelice M, Hůlková H, Sovová J, Vylet'al P,
Antignac C, Guttman M, Handsaker RE, Perrin D, Steelman S, Sigurdsson S, Scheinman SJ, Sougnez C, Cibulskis K, Parkin M, Green T, Rossin E, Zody MC, Xavier RJ, Pollak MR, Alper SL, Lindblad-Toh K, Gabriel S, Hart PS, Regev A, Nusbaum C, Kmoch S, Bleyer AJ, Lander ES, Daly MJ (2013) Mutations causing medullary cystic kidney disease type 1 lie in a large VNTR in MUC1 missed by massively parallel sequencing. Nat Genet 45:299-303

51. Bingham C, Hattersley AT (2004) Renal cysts and diabetes syndrome resulting from mutations in hepatocyte nuclear factor-1B. Nephrol Dial Transplant 19:2703-2708

52. Beck BB, Trachtman H, Gitman M, Miller I, Sayer JA, Pannes A, Baasner A, Hildebrandt F, Wolf MTF (2011) Autosomal dominant mutation in the signal peptide of renin in a kindred with anemia, hyperuricemia, and CKD. Am J Kidney Dis 58:821-825

\section{Answers}

1. D

2. E

3. B

4. A

5. E 